\title{
The Increasing of Employee Performance Through Discipline, Motivation, and Organizational Culture
}

\author{
Suwaldiyana \\ Perbankan Syariah Study Program \\ Institut Agama Islam Qomaruddin Gresik \\ Email: suwaldiyanagresik@gmail.com
}

\begin{abstract}
ABSTRAK
Tujuan penelitian ini untuk mengetahui pengaruh disiplin, motivasi dan budaya organisasi terhadap kinerja karyawan Dalam kontek perubahan Organisasi. di PT. Swadaya Graha. Sampel dengan menggunakn metode sampel total atau sensus yaitu dengan memilih langsung karyawan sebanyak 62 orang,. Teknik analisis data menggunakan regresi linier berganda. Hasil analisis regresi linier berganda membuktikan bahwa, disiplin, motivasi dan budaya organisasi terbukti mempunyai pengaruh yang signifikan secara parsial terhadap kinerja karyawan di PT. Swadaya Graha secara simultan disiplin, motivasi dan budaya organisasi juga terbukti pengaruh signifikan terhadap kinerja karyawan di PT. Swadaya Graha. Hasil tersebut dapat di artikan bahwa dengan adanya disiplin, motivasi dan budaya organisasi yang telah diterapkan dapat meningkatkan kinerja karyawan PT. Swadaya Graha.
\end{abstract}

Kata Kunci: Disiplin, Motivasi, Budaya Organisasi

\section{ABSTRACT}

The purpose of the study was to determine the effects of the dicipline, motivation, and organizational culltural on imploiyee in PT. Swadaya Graha Gresik samples using to total sample ( total sampling) on sessus by selecting direc emploiyes as many as 62 people. Data were analysed using multiple liniar regresion. The results of multiple linear regresion anlysis proved that diciplin, motivation and organizational cullture proved to have significant influince partially on the performance of employess at PT. Swadaya Graha Simultaneously dicipline, motivation, and organization culltural are also shown to significantly influense employee performance at PT. Swadaya Graha. These results can be interpreted that by their dicipline, motivation and organization culltural that has been opplied to improve the performance in employees at PT. Swadaya Graha Gresik.

Keywords: Dicipline, Motivation and Organzation Cultural

\section{INTRODUCTION}

Companies in running their business certainly need human resources who are competent and in accordance with company goals. Human resources have an important role for the company, the importance of human resources as the main driver of all activities or activities in achieving goals, as well as to maintain the company's existence starting from efforts to manage human resources, especially in increasing the effectiveness and maximum work efficiency. so that performance can be achieved at PT. Swadaya Graha Semen Indonesia Group (Persero) Tbk. In Gresik.
Mangkunegara (2013; 67) defines performance as the quality and quantity of work achieved by an employee in carrying out his duties in accordance with the responsibilities assigned to him. According to Sutrisno (2014; 151) that performance is the result of work that has been achieved by someone from their work behavior in carrying out work activities. Meanwhile, according to Wirawan $(2009 ; 5)$ that performance is the output produced by the functions or indicators of a job or a profession within a certain time. 
PT. Swadaya Graha is a subsidiary of PT. Semen Indonesia (Persero) Tbk. Gresik is a large-scale engaged in Steel Fabrication, Operation and Maintenance, Construction, Engineering which has been trusted to do the work of PT. Swadaya Graha is located at JL. RA. Kartini no 25 Gresik. The more employees who have high performance, the productivity of the overall company will increase so that the company will be able to survive in global competition. The employee is required to complete tasks and responsibilities effectively and efficiently. An interesting phenomenon in the field is an increase in the performance of PT. Swadaya Graha

PT. Swadaya Graha has increased. A person's performance is influenced by many factors, namely the opportunity to advance, job security, salary, company and management, supervision, intrinsic factors in work, working conditions, social aspects of work, communication, and facilities (Gilmer in Sutrisno, 2014; 77).

Hasibuan $(2011 ; 193)$ states that the better a disciplined employee, the higher work performance they can achieve. Sutrisno (2011; 96) discipline is the attitude of a person's willingness and willingness to comply with and obey the prevailing norms around him, and good employee discipline will accelerate the achievement of company goals, while degenerating discipline will become a barrier and slow down the achievement of company goals.

PT. PT.Swadaya Graha has established work discipline for employees as a corporate culture that must be implemented and carried out properly by all employees. Work discipline that has been carried out on employees of PT. Swadaya Graha works well and is carried out with self-awareness and responsibility. This can be seen from the neat way it works, the use of office equipment in accordance with the rules and the implementation of work in accordance with proper work procedures. This is a strength for PT. Swadaya Graha in achieving the stated goals.
Apart from discipline, motivation to work is very important for the high and low productivity of the company. Without motivation from employees to work together for the benefit of the company, the goals that have been set will not be achieved. Conversely, if there is high motivation from employees, then this is a guarantee for the success of the company in achieving its goals. (Gitosudarmo in Sutrisno, 2014; 111)

Mangkunegara (2009; 93) motivation is a condition that moves employees to be able to achieve the goals of their motives. To increase the motivation of employees of PT. Swadaya Graha provides wages, benefits and incentives according to the ability and position of employees in order to improve employee performance.

Umar (2010; 207), organizational culture is a system of shared values and beliefs taken from habitual patterns and basic philosophy of establishment which then interact into norms, where these norms are used as guidelines for how to think and act in an effort to achieve common goals. . The organizational culture applied by PT. Swadaya Graha to improve employee performance, including five minute meetings, concise, neat, neat, caring, diligent (5 $\mathrm{R}$ ), and work attitude on time (SKTW).

Based on the description on the background above, the researcher conducted a study on Improving Employee Performance through Discipline, Motivation and

Organizational Culture. Specifically, the objectives of this study were: a) to determine the partial effect of discipline on the performance of PT. Swadaya Graha, b) to determine the effect of motivation partially on the performance of employees of PT. Swadaya Graha, c) to determine the effect of organizational culture partially on the performance of employees of PT. Governmental Graha, and d) to determine the discipline, motivation and organizational culture simultaneously influence on employee performance PT.Swadaya Graha Gresik 


\section{LITERATURE REVIEW \\ Work Discipline}

Hasibuan (2011: 193) defines the discipline as awareness and one's willingness to comply with all company rules and norms prevailing social norms. According to Sutrisno (2014: 87) that discipline is the attitude of a person's willingness and willingness to obey and obey the prevailing regulatory norms around him.

Fitriana and Agustina (2012) concluded that discipline is the attitude of employees to comply with the regulations set by the organization or agency. Discipline is the willingness of employees to obey or as well as the norms that apply within the company, be it written rules or unwritten rules (Permatasari, et al, 2015).

From some of the opinions above, it can be concluded that discipline is the readiness of an employee / employee to comply with and obey the rules and social norms that apply discipline. Singodimedjo in Sutrisno (2014: 89) factors that influence employee discipline are:

1. The size of the compensation.

The size of the compensation can affect the upholding of discipline. Employees will comply with applicable regulations, if they feel that they are guaranteed remuneration that is commensurate with what has been contributed to the company.

2. Whether or not there is an exemplary leadership in the company.

Keteladan leadership is very important, because in the discipline of the organization or institution, all employees will always pay attention to how the leadership to discipline himself and how he can control himself through words, actions, and attitudes that can be detrimental to the disciplinary rules that have been defined.

3. Whether there are definite rules that can be used as a guideline.

Discipline fostering will not be carried out in an agency or organization, if there are no definite written rules to be used as a common reference.
4. Leadership courage in taking action If there is an employee who violates discipline, it is necessary to have the courage of the leader to take action on the appropriate punishment in accordance with the violation committed.

5. Whether there is leadership supervision or not.

In every activity undertaken by an organization or agency needs to be supervision of a leader, where the leaders are expected to direct the staff to carry out the work correctly and in accordance with what has been set.

6. Whether there is concern for employees

Employees are human beings who have differences in character from one another.

7. Habits are created that support the upholding of discipline.

Sutrisno $(2014 ; 194)$ states that a good organization or company must strive to create rules or regulations that will become signs that must be fulfilled by all employees in the organization. Regulationsthat will be related to discipline include, among other things,

1. Adherence to the provisions of entry, return and rest hours.

2. Adherence to basic rules regarding dress and behavior in work.

3. Compliance with standard operating procedures (SOP) in carrying out work.

4. Regulations on what employees can and cannot do while in the organization and so on. (Singodimejo, 2000)

Rivai (204: 444) work discipline is a tool used by managers to communicate with employees so that they are willing to change a behavior as well as an effort to increase awareness and willingness of a person to obey company regulations applies.

Basically, work discipline always hopes that it will characterize every human resource in the organization, because with discipline the organization will run well and can achieve its goals well (Setiawan and Waridin, 2006: 189). Work discipline has a positive influence on employee performance. Employees who are 
disciplined in work since leaving, at work and when they come home from work and according to the rules at work, will usually have a good performance. It can be concluded, the higher the work discipline, the higher the employee's performance.

\section{Motivation}

Motivation is what causes, channels, and supportsMotivation is human behavior, so that they want to work hard and enthusiastically to achieve optimal results. increasingly important because managers give jobs to subordinates to be done well and integrated to the goals set by Hasibuan, (2007: 235). Every activity carried out by someone is driven by a force from within a person, this driving force is called motivation. According to Robbin (2012: 98) motivation is a process that explains the intensity, direction and persistence of individuals to achieve goals.

The mental or psychological atmosphere of a worker as an individual in the organization or company society that becomes his work discipline, has a very big influence on the implementation of work. Thismental atmosphere is seen in the spirit of work passion which results in work activities as a contribution as a contribution to the achievement of Nawawi's company business goals (206 : 97). Motivation is a psychological process that evokes and exerts behavior towards goal achievement or goal-directed behavior. According to Siregar (2007: 89) that work motivation is something that creates a desire for a person or worker, either from within or from outside to carry out a job or activity with a sense of responsibility in order to achieve the goal desired.

Meanwhile, according to Hasibuan (2010: 99) divides motivation into the following: intensive material, intensive non-, a combination of material and non-. From some of statements these, it can be stated that motivation is a driving force that comes from within and from outside a person as a trigger and reason to work optimally in order to achieve what is desired.
Based on the understanding of motivation from some of the opinions above, motivation is a driving factor that can create employee morale to achieve organizational goals. Thus, people who are motivated will put more effort into those who are not. Companies or organizations not only expect capable, competent, and skilled employees, but what is important is that they are willing to work hard and are willing to achieve maximum work results. The abilities and skills of employees are meaningless to the company if they do not want to work hard.

There are several objectives obtained from providing motivation according to Hasibuan (2010: 87), is:

1. Increasing employee morale and job satisfaction.

2. Increase productivity employee work employee

3. Maintain Stability.

4. Improve employee discipline.

5. Effective employee procurement.

6. Create a good working atmosphere and relationship.

7. Increaseloyalty, creativity, and participation employee

8. Increase the level of welfare employee

9. sense of responsibility of employees towards their duties,

10. Increase theIncrease the efficiency of the use of tools and raw materials.

Hasibuan (2010: 231) there are two types of motivation, namely:

1. Positive motivation, which means that managers motivate their subordinates by giving prizes to those who excel above achievements standard. With motivation positive, the morale of subordinates will increase because generally humans are happy who are doing well.

2. Negative motivation, meaning that managers motivate by standards there will be punished. With motivation this negative, the subordinates' work enthusiasm in the short term will increase because they are 
afraid of being punished, but in the long term is negative can have consequences.

The level of motivation between one individual and another varies and in an individual at different times. Maybe you can It is said that the most famous theory of motivation is the hierarchy of needs expressed by Abraham Maslow. Maslow identified five levels in the hierarchy of needs, namely: Hasibuan 2010: 145)

1. Physiological Needs

Need to survive. What is meant by this need is the need for food, drink, air and so on. The desire to meet this need stimulates a person to behave or work actively.

2. Safety and security needs.

The need for freedom from threats, namely feeling safe from the threat of accidents and safety in carrying out work.

3. Social needs

Social needs, friends, interactions are loved and loved, and accepted in the association of a group of workers and society disciplined

4. Need for appreciation

The need for self-esteem and recognition and prestige awards from employees and the society disciplined.

5. Self-actualization

The need for self-actualization by using skills and optimal potential to achieve very satisfying work performance is extraordinary.

Robbins (2012: 132) needs theory McClelland's states that the theory states that achievement, strength, and relationships are the three most important needs that help explain motivation. Those things are defined as follows:

1. The need for achievement

The drive to exceed, reach the standardstandard,striving for success.

2. Need for power

The need to make other individuals behave in such a way that they will not behave the way others around.

3. The need for affiliation
The desire to establish a relationship interpersonal that is friendly and familiar.

Hasibuan (2011: 141) the importance of motivation because motivation is what causes, channels and supports behavior human so that they are willing to work more actively and enthusiastically to achieve optimal things. Without motivation from employees to work together for the benefit of the company, the goals that have been set will not be achieved. Conversely, if there is high motivation from employees, then this is a guarantee for the success of the company in achieving its goals. (Gitosudarmo in Sutrisno, 2014; 111).

\section{Organizational Culture}

Organizational culture as a social unit established by humans in a relatively long period of time to achieve goals by forming a strong soul in order to be face the tasks assigned in the company. In addition, organizational culture can teach about the meaning of togetherness in achieving goals and not individualism. According to Davis (2006: 29) organizational culture is a pattern of beliefs and values as an organization that is understood, imbued and practiced by the organization so that the pattern provides its own meaning and becomes the basis for rules of behavior. in the organization so that it has a volume and work motivation that must be realized in order to realize organizational goals. The same thing is also expressed by Mangkunegara (2009: 113) which states that culture organizational is a set of assumptions or belief systems, values, and norms developed within the organization that serve as guidelines for behavior for its members to overcome adaptation problems external and internal. .

Thus it can be concluded that organizational culture is a pattern of beliefs and values that are believed and inspired by all members in doing work as the right way to understand, think about, and feel about problems.

Some experts have suggested elements of organizational culture, such as Hasibuan (2010: 
215), among others: values, beliefs and basic principles, and management practices and behavior, namely: shared basic assumption patterns, values and ways of looking at thinking and feel, and the artifacts (cultural outcomes) that exist within the organization. Regardless of the differences in how many elements of organizational culture from each expert, therefore it can be taken in general that elements of organizational culture consist of two main elements, namely elements that are idealistic and elements that are behavioral.

1. Idealistic elements are generally unwritten, four organizations that are small attached to the owner in the form of doctrine, philosophy of life, or values individuals of the founder or owner of the organization and serve as guidelines for determining the direction of the goals of carrying out the daily life of the organization. This idealistic element is usually stated formally in the form of a written guideline statement, the goal is none other than so that the organizational ideology remains sustainable.

2. Behavioral elements are elements that are visible to the eye, appearing to the surface in the form of behavior daily of its members, logos or jargon, ways of communicating, how to dress.

Robbins (2008: 208) states that to assess the quality of the Organizational Culture of an organization can be seen from seven main factors, namely:

1. Initiative Individual, namely the level of responsibility, freedom and independence of the individual.

2. Tolerance for risky actions, namely the extent to which employees are encouraged to act aggressively, be innovative, and dare to take risks.

3. Direction, namely the extent to which the organization creates clear goals and expectations regarding achievement.

4. Integration, namely the degree to which units in the organization are encouraged to work in a manner coordinated
5. Management support, namely the degree to which managers provide clear communication, assistance and support to their subordinates

6. Control, namely the number of direct regulations and supervision used to supervise and control employee behavior.

7. Identity, namely the degree to which members identify themselves as a whole with their organization rather than with certain work groups or with professional areas of expertise.

The function of organizational culture can provide boundaries within the organization in each run work units so as to provide an organization, better and can provide the stability of the social system in the organization. In addition, Robbins (2008: 245) divides the six functions of organizational culture, as follows:

1. Role in setting individual boundaries in the organization.

2. Delivering a feeling of identity as a member of the organization.

3. It is easy to have a broad commitment than interests individual someone.

4. Increase the stability of the social system.

5. Help unify the organization

6. As a control mechanism and be rational that guide and shape the attitudes and behavior of employees of

Kreitner and Kinicki (2001) in Wibowo (2010: 30) suggests the existence of 3 (three) common type of organizational culture, among others:

1. Culture constructive (constructive culture) is a culture in which workers are encouraged to interact with others and work on tasks and projects in a way that will help them satisfy their need for growth and development

2. A passive-defensive culture has the characteristic of rejecting the belief that workers should interact with other people. in a way that doesn't challenge safety their own.

3. Culture aggressive-defensive aggressive(defensiveculture) encourage workers 
approached the task by means of force with the intent of protecting the status.

Deal and Kennedy (2007: 56) suggest that the characteristics of organizations that have a strong organizational culture are as follows:

1. Organization members are loyal to the organization, know and are clear about the goals of the organization and understand behavior which is considered good and bad.

2. The code of conduct for people within the agency is clearly outlined, understood, obeyed, and implemented by the people in the agency so that the people who work are very cohesive.

3. The values adopted by the organization do not only stop at the slogan, but are lived up to and expressed in daily behavior consistently by people who work in the agency, from those with the lowest rank to the highest leaders

4. Organizations / agencies need a special place for heroes.-Instance heroes and systematically create various hero levels, for example, best advice provider, innovator of the year, and so on.

5. Has a cultural network that accommodates the stories of its heroes. A strong organizational culture becomes a mechanism control that becomes rational that guides and shapes the attitudes and behavior of employees so that it greatly affects performance, as stated by Robbins (2008: 18) through several indicators such as:

a. Direction, namely that each member of the organization has a direction determined by their leadership in achieving goals as well as in institutions the private sector, each agency must be directed by the leadership to achieve the goals to be achieved.

b. Initiative, namely the freedom given by organizations to individuals in expressing ideas to be able to get better progress, this is also done by private companies, where each employee has the right to put forward existing ideas to get performance a goodin the company, and obtain progress of a company.

c. Sincerity is a job that is done sincerely and sincerely in carrying out a job that is given by the company.

d. Integrity is an attitude and mentality that upholds the value of truth in an organization. This needs to be done by the company, because in the company when carrying out their duties, employees can carry out their duties based on procedures based on the rules of the company.

e. Communication patterns, namely the extent to which communication in an organization that is limited by a formal hierarchy of authority can run well.

f. Control, namely the existence of supervision from the leaders of the employees by using the rules that have been established for the smooth running of the organization.

From these indicators, Thoha (2011: 79) suggests that organizational culture can be influenced by the performance of groups, individuals and structures. Because any institution must have groups, individuals and structures that work to achieve the goals of the organization.

Organizational culture is a system of shared meanings held by members that differentiates the organization from other organizations (Robbins, 2006; 721). In every organization, a work culture is always expected to be good because a good work culture will relate to the success or failure of organizational goals. With a good organizational culture. Usually the organization will easily overcome the problems faced and can achieve organizational goals by relying on the existing strengths in the organization (Setiawan and Waridin, 2006; 190). The existence of a good organizational culture, usually can affect employee performance. It can be concluded, the 
better the culture of an organization, the better the employee's performance.

\section{Performance}

Mangkunegara $(2013 ; 67)$ defines the quality and quantity of work achieved by an employee in the ability to carry out tasks in accordance with the responsibilities given to him by superiors. .

Sedarmayanti (2011) in Jacob (2014) performance is what can be achieved by a person or group of people in an organization, in accordance with their respective authorities and responsibilities, in an effort to achieve the goals of the organization concerned illegally, not violating the law accordingly.

From some of the opinions above, it can be concluded that performance is the result of work achieved by someone from their work behavior in carrying out their work activities in order to achieve the goals of the organization concerned legally, does not violate the law and is in accordance with morals or a description of the level of achievement of the implementation of an activity / program. wisdom in realizing the goals, objectives, mission and vision of the organization.

Mangkunegara $(2013 ; 67)$ states that the factors that influence performance achievement are as follows:

1. Ability Factors

Psychologically, the ability consists of the ability (IQ) and the reality ability (knowledge + skill) , meaning that employees who have an IQ above average (IQ (110-120) with adequate education for his / her staff to be skilled in doing daily work, it will be easier for them to achieve the expected performance. Therefore, employees need to be placed in jobs that are in accordance with their expertise (the right man in). the right place, the right man on the rightjob).

2. Factors Motivation.

Motivation is defined as an attitude of managers and employees to work situations disciplined organization. They will show positive or negative value to the work situation, and it can show how high the lack of motivation of the leadership and employees,

Byar and Rue in Sutrisno (2014; 151), suggests that there are two factors that influence performance, namely individual and disciplinary factors. Factors that the individual in question is:

1. Effort which shows a number of physical and mental energy that is used in carrying out the task of movement.

2. Abilities, namely characteristics personal needed to carry out a task.

3. role task perception, namely all behaviors and activities that feel necessary individuals to complete a job.

The future-oriented appraisal method, using the assumption that employees are no longer subject to and dependent on supervisors, but employees are involved in the appraisal process. According Veithzal Rival (2011; 573), while the techniques used are:

1. Self Appraisal

2. Management By Objective

3. Ratings psychologically

4. Assessment centers

Indicators of Performance Measurement, Mathis and Jackson $(2002 ; 78)$ indicators of performance are:

1. Quality : the quality of work produced. The indicator is the number of assignments made by employees, and the number of improvements or complaints from superiors.

2. Quantity : the amount of work produced, the indicator is the number of tasks that can be completed by the employee.

3. Timelines : Deadlines for each task completion according to schedule a specified. The indicator is the standard time for completion of work by employees.

4. Need of supervision : the need for supervision and attendance. The indicator is the frequency of supervision, and works effectively according to working hours determined. 
5. Interpersonal impact : the level of an employee shows the cooperation around him / her. The indicators are the ability to influence other employees, and the ability to work with other employees.

\section{Hypothesis}

Based on the description of the theory and the relationship between the proposed hypothesis variables, it is

1. suspected that there is a partial influence of discipline on the performance of the employees of PT. Swadaya Graha.

2. It is suspected that there is a partial influence of motivation on the performance of the employees of PT. Swadaya Graha.

3. It is suspected that there is a partial influence of organizational culture on the performance of employees of PT. Swadaya Graha.

4. It is suspected that there is a simultaneous influence of discipline, motivation and organizational culture on the performance of the employees of PT. Swadaya Graha.

\section{METHODE}

\section{The Research Approach}

The research to be carried out is quantitative research, namely systematic scientific research on the parts and phenomena and their relationships. According to Sugiyono (2008; 78). Quantitative measurement is the definition, measurement of quantitative data and statistics objective through scientific calculations derived from a sample of people or residents who are asked to answer a number of questions about a survey to determine the frequency and percentage of their responses.

\section{Population and Sample}

Sugiyono $(2008 ; 80)$ of the population is generalization region consisting of the above objects and subjects that have certain qualities and characteristics defined by the researchers to learn and then drawn conclusions.The population referred to in this study are permanent employees of PT. Swadaya Graha, totaling 62 employees. According to Sugiyono $(2008 ; 81)$ states that the sample is part of the number and characteristics possessed by the population. The sampling method in this research is research that uses all members of the population called the sample total (total sampling) or census. The use of this method is valid if the members of the population are relatively small (easy to reach). In this study, because the population is relatively small and relatively easy to reach, the authors use the total sampling method. With this sampling method, it is hoped that the results will tend to be closer to the real value and are expected to also minimize the occurrence of errors or deviations from the population values. Usman \& Akbar, $(2009 ; 45)$ in this study the sample taken was 62 permanent employees.

\section{Identification Variables}

In accordance with the hypothesis,to understand the phenomenon that is observed then that variable is in this study is the independent variable is a variable that affects or is the cause of the change or the emergence of the dependent variable.

The independent variables were used in this study a) discipline (X1), b) motivation (X2), and Organizational (X3). The dependent variable is a variable that is affected or which become due, because of the independent variables. This study being is tied to employee performance.

\section{Variable Measurement}

Variable measurement is done by using a questionnaire that is filled in by the respondent. Measurement of the questionnaire in this study using a Likert scale is made in tabular form. That the Likert scale is a scale that contains five levels of preference answers with details from strongly agree to strongly disagree

\section{Data Collection Techniques}

This research data collection technique using a questionnaire method (questionnaire).The questionnaire is to obtain 
data by submitting a complete written list of questions about the issues to be discussed, about work discipline, motivation, organizational culture, and employee performance of permanent employees of PT. Swadaya Graha which is located on Jl. RA. Kartini No.25 Gresik 61151 East Java.

\section{Instrument Test}

Before being used in further analysis, the instrument in this study was first tested for the validity and reliability of the instrument using SPSS (Social Product of Social Science).

\section{Classical Assumption Test}

Multiple linear models can be called a good model if the model meets the classical statistical assumptions which include the following: 1) Autocorrelation, 2) Multicollinearity, and 3) Heteroscedasticity

\section{Data Analysis Techniques}

Quantitative analysis is used to analyze numerical data or in the form of numbers. The data source used in this study is primary data collection using a questionnaire. The data is quantified by providing a score for each respondent's answer (Sugiyono, 2010; 86). Henceforth, the data obtained were analyzed with Multiple Linear Regression Analysis. Regression analysis is basically a study of the dependence of the dependent variable with one or more independent variables with the aim of predicting the average value of the dependent variable based on the known value of the independent variable (Ghozali, 2009; 43). ). The equation of multiple linear regression lines can be written as follows: $\mathrm{Y}=\mathrm{a}+\mathrm{b} 1 \mathrm{X} 1+$ $\mathrm{b} 2 \mathrm{X} 2+\mathrm{b} 3 \mathrm{X} 3+\mathrm{e}$

\section{Hypothesis Test}

To test a hypothesis put forward by the researcher. Then a statistical test was carried out, with the $\mathrm{t}$ test and $\mathrm{F}$ test.

\section{RESULTS AND DISCUSSION}

Respondents' Description
That the highest percentage of sex was male, namely 43 respondents or $69 \%$, and the lowest percentage of sex was female, namely 19 respondents or $31 \%$. This shows that employees at PT. Swadaya Graha The majority of the sex is male. The number and percentage of respondents in this study were dominated by the age of 28-37 years with the number of respondents as much as 30 or $48 \%$, this shows that employees at PT. The majority of Swadaya Graha are 28-37 years old. The number of respondents with $\mathrm{S} 1$ education $=10$ respondents,education Diploma $=6$ respondents, education Senior high school $=46$ Respondents

\section{Instrument Test}

The results of the instrument validity test for all variables obtained rcount $>$ rtable $=$ 0.2461 So all questions from independent and dependent variables proved valid. While the reliability test results show that each variable value Cronbach Alpha is greater than 0.70. Thus it can be concluded that the measuring instrument used in this study is reliable.

\section{Classical Assumption Test}

Tests that have been carried out with Durbin-Watson results of 2,100, with calculations through the Durbin-Watson table where $\mathrm{k}=3$ (number of independent variables independent) and $\mathrm{N}=62$ (number of samples), then the value of $\mathrm{du}$ is 1.696 , the value of 4 -du is 2.304 and $\mathrm{dl}$ value is $1.696,4-\mathrm{dl}$ value is 2.497 then these values fit into the Durbin Watson curve, so it is concluded that there is no autocorrelation. For multicollinearity testing, the Variance Inflation Factor (VIF) value is not more than 10 and the Tolerance (TOL) value is not less than 0.1 , it can be concluded that the regression model does not have multicollinearity problems. In the Heteroscedasticity test using the Glejser test, the basis for making best decisions heteroscedasticity through the Glejser test is if the sig> 0.05 then there are no symptoms heteroscedasticity (Ghozali, 2013; 143). Based on data processing in mind that the value of 
labor discipline glejser test (X1)0,153, motivation $((\mathrm{X} 2) 0,751$ and organizational culture (X3)0.213 indicates that there are no symptoms heteroskedasticity because the sig> 0.05 .

\section{Analysis of Data}

Analysis the data used in this research is multiple linear regression with performance $(\mathrm{Y})$ as the dependent variable. the variables independently is work discipline(X1),motivation work (X2),organizational culture (X3). The test is performed with the help of SPSS showed in table 1 below:

Table 1: Multiple Linear Regression

\begin{tabular}{|c|c|c|c|c|c|c|}
\hline \multirow[b]{2}{*}{ Mode } & & \multicolumn{2}{|c|}{$\begin{array}{l}\text { Unstandardoed } \\
\text { Coefficients }\end{array}$} & \multirow{2}{*}{$\begin{array}{c}\text { Standarouced } \\
\text { Coeficients } \\
\text { Beta }\end{array}$} & \multirow[b]{2}{*}{$t$} & \multirow[b]{2}{*}{ Sig. } \\
\hline & & B & Std. Emor & & & \\
\hline \multirow[t]{4}{*}{1} & (Constant) & 315 & 1.776 & & .177 & .880 \\
\hline & TOTALX1 & 261 & .094 & 250 & 2.792 & .007 \\
\hline & TOTALX2 & 321 & 005 & 388 & 3.388 & .001 \\
\hline & TOTALX3 & 365 & .130 & 303 & 2.733 & .008 \\
\hline
\end{tabular}

Table 1 above multiple linear regression equation is described as follows:

$\mathrm{Y}=0.315+0,261 \mathrm{X} 1+0,321 \mathrm{X} 2+0,355 \mathrm{X} 3$

1. The constant value of 0.315 indicates if the work discipline (X1), work motivation (X2), and organizational culture (X3), have a value of 0 , then the magnitude of the employee performance variable $(\mathrm{Y})$ is 0.315 .

2. The value of work discipline is 0.261 indicating that if work discipline (X1) changes, then $\mathrm{Y}$ will be 0.261 units, with the assumption that work motivation (X2) and work discipline (X3) are constant, meaning that the higher the work discipline, the employee performance will increase and assume other variables are constant.

3. The work motivation value of 0.321 shows that if work motivation (X2) changes with one unit of value, then $\mathrm{Y}$ will be 0.321 units, assuming work discipline (X1) and work discipline (X3) are constant, meaning the better work motivation, then employee performance will increase and assume other variables are constant.

4. The organizational culture value of 0.351 shows that if the organizational culture (X3) changes with one unit of value, then $\mathrm{Y}$ will be 0.351 units, assuming work discipline (X1) and work motivation (X2) are constant, meaning that the better the organizational culture, then employee performance will increase and assume other variables are constant.

\section{The Coefficient Of Determination (R2) and The Multiple Correlation Coefficient}

Correlation coefficient (R) is used to determine the relationship between the independent variable $(\mathrm{X})$ on the dependent variable (Y) together. The coefficient of determination (R2)essentially measures how far the model's ability to explain variations in the independent variable. The results show that the value of Adjusted $\mathrm{R}$ square 0.530 means that the change in the dependent variable of performance $(\mathrm{Y})$ of $53 \%$ is caused by the variables of work discipline (X1), work motivation (X2), and organizational culture (X3), while $46 \%$ is due to by factors other than these variables.

\section{Hypothesis Test}

Hypothesis testing of this research is that there is an influence partially and simultaneously or jointly with work discipline variables (X1), work motivation (X2) Organizational culture (X2), on employee performance ( $\mathrm{Y}$ ) Hypothesis testing is done by using techniques statistical test (partial) and $\mathrm{F}$ test (simultaneous)

\section{t test (partial)}

This test is used to test how far an independent (independent) variable individually explains variations in the dependent variable (dependent). Tests carried out with the help of SPSS obtained results as in table 1 by looking at the table value and its significance value. The results show that: a) tcount $>$ ttable with a 
significant value of 5\%, thus partially the work discipline variable is proven to have a significant effect on the performance of the employees of PT. Swadaya Graha. The following is a picture of the curve of the area of acceptance and rejection of the Ho t test (work discipline), b) The results of the research on the work motivation variable obtained the $t$ value. amounting to 2.388 while the $t$ table of 2,000 this result shows that tcount $>$ ttable with a significance of $5 \%$. Thus partially work motivation variable proved to have a significant effect on the performance of employees of PT. Swadaya Graha, c) The results of research on organizational culture variables obtained $t$ value amounting to 2,733 while the t table of 2,000 this result shows that tcount $>$ ttable with a significance of $5 \%$. Thus partially the organizational culture variable proved to have a significant effect on the performance of the employees of PT. Swadaya Graha. The following is a picture of the curve of the acceptance and rejection of the Ho Test $t$ (organizational culture).

\section{F test (Simultaneous)}

This test is used to test the effect of the hypothesis simultaneously, namely it is suspected that work discipline, work motivation and organizational culture have a simultaneous influence on the performance of the employees of PT. Swadaya Graha. This test was carried out with the help of the SPSS application, the results showed that the regression value has a significance level of 0.00 this value is less than 0.05 or the significance value $<\alpha$ and Fcount has a value of 23,962 while the Ftable has a value of 2.76 this means that Fcount > Ftable, so that $\mathrm{Ho}$ is rejected and $\mathrm{Ha}$ is accepted, meaning that simultaneously there is a significant effect of work discipline (X1), work motivation (X2), organizational culture (X3), on employee performance (Y).

\section{Discussion}

Based on the research and analysis studied using the SPSS 21 application tool for windows, the researcher can interpret the results as follows:

1. Partially proving the regression hypothesis using the $t$ test is intended to determine the effect of each independent variable consisting of work discipline (X1), work motivation (X2) and organizational culture (X3) partially on the dependent variable, namely employee performance ( $\mathrm{Y}$ ).

a. Work Discipline (X1) obtained t count of 2.792 while the $t$ table was 2,000 at a significant level of $5 \%$. Thus the results of statistical calculations prove that partially the work discipline variable (X1) is proven to have a significant effect on employee performance at PT. Swadaya Graha is in accordance with the opinion of Rivai (204: 444) and Setiawan and Waridin, (2006)gets

b. Work motivation (X2)t count of 3,388 while $\mathrm{t}$ table is 2,000 at $5 \%$ significant level. Thus the results of statistical calculations prove that partially the work motivation variable (X2) is proven to have a significant effect on employee performance at PT. Swadaya Graha is in accordance with the opinion of Hasibuan (2011: 141) and Gitosudarmo in Sutrisno, $(2014 ; 111)$

c. Organizational culture (X3) obtains t count of 2,733 while $t$ table is 2,000 at a significant level of $5 \%$. Thus the results of statistical calculations prove that partially the organizational culture variable (X3) is proven to have a significant effect on employee performance at PT. Swadaya Graha in accordance with the opinion of Robbins, (2006; 72); and Setiawan \& Waridin, $(2006 ; 190)$

2. Simultaneous hypothesis testing using the $F$ test, it was found that the regression value has a significance level of 0.00 this value is less than 0.05 or the significance value $<\alpha$ 
and $\mathrm{F}$ count has a value of 23,962 while the Ftable has a value of 2.76 , this means Fcount > Ftable, so that Ho is rejected and $\mathrm{Ha}$ is accepted, meaning that it is proven that work discipline (X1), work motivation (X2), and organizational culture (X3) have a significant effect simultaneously on performance $(\mathrm{Y})$ employees at PT. Swadaya Graha according to Mangkunegara $(2013 ; 67)$ that performance achievement is influenced by ability factors, motivational factors, Byar and Rue in Sutrisno $(2014 ; 151)$, suggest that there are two factors that affect performance, namely individual and disciplinary factors. Factors that individuals who are: a) The Effort (effort) which shows a number of physical and mental energy that is used in organizing the movement of duty, b) Abilities, namely personal properties required to perform a task, c) role task perception, namely all the behaviors and activities that individuals feel are necessary to complete a job.

\section{CONCLUSION}

Based on the results of data processing in this study, the following conclusions can be drawn: a) Work discipline has a partially significant effect on employee performance at PT. Swadaya Graha, b) Work motivation partially significant effect on employee performance at PT. Swadaya Graha c) Organizational culture has a partially significant effect on employee performance at PT. Swadaya Graha. d) Work discipline, work motivation and organizational culture simultaneously have a significant effect on employee performance at PT. Swadaya Graha. Researchers recommend to 1) Company: that based on the results of $t$ count the variable that shows the lowest value is organizational culture compared to other variables, namely work discipline and work motivation, so to build high performance it is necessary to pay attention to the implementation of organizational culture, including the leadership maintaining understanding of the order workplace in order to control the culture that exists in the workplace, the company is constantly looking for ways for employees to work more effectively, the company facilitates good employee relations to always work well together as a team and the company is responsive so that employees adapt quickly to new environment. 2) For future research, it is expected that we try to elaborate topics related to performance given the coefficient of determination $(53 \%)$ which allows the addition of new variables in this study.

\section{REFERENCES}

Akbar \& Usman. (2009). Metode Penelitian Sosial. Jakarta: Bumi Aksara

Davis, Keith dan Newstorm, (2006). Perilaku Dalam Organisasi. Edisi Tujuh,Erlangga, Jakarta

Ghozali, Imam, (2009), Aplikasi Analisis Multivariate Dengan Program SPSS, Semarang: Badan Penerbit Universitas Diponegoro, Vol.100-125.

Hasibuan, Malayu S.P, (2011). Manajemen Sumber Daya Manusia. Jakarta:PT Bumi Askara.

Kreitner, Robert dan Angelo Kinicki, (2001). Organizational Behavior. New York: McGraw-Hill Companies, Inc.

Mangkunegara, A.A., \& Anwar, P. (2012). Manajemen Sumber Daya Manusia. Bandung: PT. Remaja Rosdakarya.

Mathis Robert, Jackson John. (2002). Manajemen Sumber Daya Manusia. Jakarta : Salemba empat

Nawawi, Hadari. (2006). Evaluasi dan manajemen kinerja di lingkungan perusahaan dan industri. Yogyakarta: Gadjah Mada Univercity Press.

Permatasari, Jundah Ayu, Mochammad AL Musadieq dan Yuniadi Mayoman, (2015), Pengaruh Disiplin Kerja Dan Motivasi Kerja Terhadap Prestasi Kerja Karyawan, Jurnal Administrasi Bisnis, Vol. 25 No. 1, Agustus, hal 1-9 
Rivai, Veithzal, (2004). Kepemimpinan dan Prilaku Organisasi, Raja Grafindo Persada, Jakarta.

Robbin Steven P.(2012), Organizational Behaviour , Tenth Edition ( Perilaku Organisasi Edisi ke sepuluh ) Salemba Empat , Jakarta.

Robbins, Stephen P.(2008), Perilaku Organisasi ( alih bahasa Drs. Benjamin Malan ) edisi Bahasa Indonesia . PT. Intan Sejati, Klaten.

Robbins, Stephen. P. (2006). Perilaku Organisasi (alih bahasa Drs. Benjamin Molan), Edisi Bahasa Indonesia, Klaten: PT INTAN SEJATI.

Sedarmayanti. (2011). Manajemen Sumber Daya Manusia. Reformasi Birokrasi dan Manajemen Pegawai Negeri Sipil, Cetakan Kelima, PT Refika Aditama, Bandung

Setiyawan, Budi dan Waridin. (2006). Pengaruh

Disiplin Kerja Karyawan dan Budaya Organisasi Terhadap Kinerja di Divisi Radiologi RSUP DokterKariadi, Semarang: JRBI. Vol 2. No 2. Hal: 181198

Singodimedjo, Markum.(2000). Menejemen Sumber Daya Manusia. Surabaya :SMMAS

Siregar, N.I. (2009). Hubungan antara Persepsi Terhadap Gaya Kepemimpinan dengan Disiplin Kerja pada Karyawan PT. Perkebunan Nusantara III Medan. Jurnal Analitika Volume I No. 1 Juni 2009: 6877.

Sugiyono, (2008). Metode Penelitian Bisnis. Bandung. Alfabeta

Sugiyono. (2013). Metode Penelitian Kuantitatif, Kualtitatif dan $\mathrm{R}$ \& D. Bandung: Alfabeta.

Sutrisno, Edi, 2014, Manajemen Sumber Daya Manusia, Cetakan Ke-6, Kencana Prenada Media Grup, Jakarta

Thoha, Miftah, (2009). Kepemimpinan dalam Manajemen, Edisi Pertama, Rajawali Pers, Jakarta.
Wibowo. 2006. Manajemen Perubahan. Jakarta: PT. Raja Grafindo Persada. Wirawan. (2009). Evaluasi Kinerja Sumber Daya Manusia Teori Aplikasi dan Penelitian. Jakarta. Penerbit: Salemba Empat 